\title{
The Role of Youth in Overcoming Problems Related Sinabung Volcano Eruption
}

\section{| Yesi Chairani Tanjung ${ }^{1,{ }^{*}}$ | Erika Revida Saragih ${ }^{2}$ | Agus Purwoko ${ }^{3}$ |}

\author{
${ }^{1}$ Student of Master of \\ Regional and Rural \\ Development Planning, \\ University of North \\ Sumatra, Medan, \\ Indonesia. \\ 2,3 Lecturer in Master of \\ Regional and Rural \\ Development Planning, \\ University of North \\ Sumatra, Medan, \\ Indonesia.
}

'yesichairani63@gmail.com

\begin{abstract}
Youth is one of the important human resources to increase their capacity. The number developed sufficiently. It shows that the nation's change is occurred very significant. In the disaster management, the youth certainly has a very important role to maintain the regional resilience. So that young people must be prepared to overcome threats and challenges related disasters that cannot be predicted. This study aims to determine how the role of youth in overcoming problems related Sinabung Volcano Eruption in Tiganderket Sub-District, Karo District, North Sumatra. This research uses qualitative methods. In this study, there are three informants interviewed. They are; 1) The Secretary of BPBD (Regional Disaster Management Agency, Karo District, 2) Youth Leaders, and 3) The local community who were presented in the form of scientific analysis. The results of this study indicate that: The Effectiveness of Youth's Role in overcoming Sinabung Volcano Eruption, Tiganderket Sub-district, Karo District, North Sumatra has not been able to tackle effectively. It can be measured from the level of Youth involvement to play a role in overcoming the disaster. It can look from the three phases which are Pre disasters, During-disasters, and Post-disasters. The youth in Tiganderket Sub-district Only involved when the disaster happened.

KEYWORDS

The role of youth; effectiveness; overcoming disaster; Sinabung Volcano eruption
\end{abstract}

\section{INTRODUCTION}

Indonesia is a prone country to get disaster. It happened because some aspect which are geographical, geological, hydrological and demographic aspects. Sinabung Mountain is located in the highlands of Karo Disctrict, precisely in Simpang Empat and Tiganderket Sub-district. The surrounding land is a fertile farming place and indirectly provides the economic benefits for people who are around Sinabung Mountain. In 2010, Sinabung Mountain which had been considered the inactive mountain for the first time, experienced an eruption after hundreds of years showing no signs of its activity. This disaster makes people who are on the slopes of Sinabung Mountain, especially in a radius of $3 \mathrm{~km}$ evacuated to safer areas, especially in the capital city of Karo District, namely Kabanjahe District and Berastagi District around it. In the effort of disaster management Karo District is one area that has a high level of disaster risk, so it is very much needed special handling in this region which there are four Sub-districts directly affected by the eruption of Sinabung Mountain namely Simpang Empat Sub-district, Naman Teran Sub-district, Payung Sub-district and Sub-district Tiganderket. Youth participation and role in disaster management is needed to help disaster risk reduction. This was also reviewed based on Law Number 40 of 2009 Article 16 concerning the role of youth in national development. 
Youth is an important component of this nation. The number of youth, which reaches 65 million, shows that the number of youth is very significant in every dynamic change in the nation. In addition to being an economic asset, youth are classified as productive age (based on the Youth Law, the age of youth is 16-30 years old), are also assets in the fields of ideology, politics, social and culture. So apart from the economic category, youth is also part of the social category.

In carrying out various important roles, besides facing threats to democracy, youth also face the challenge of how to compete with a nation that is already globalizing. In the concept of regional resilience, youth has a very important role in disaster management efforts in Indonesia. Therefore, youth must be prepared to face threats and challenges in facing disasters. One of the values that must always be present in youth is an attitude of preparedness in maintaining regional resilience. It is an important agenda for all of us to recultivate the spirit of youth preparedness considering the location of the Indonesian state which is located on a very active earth plate, which is marked by a lot of earthquake and volcanic activity.

The participation and role of youth in disaster management is urgently needed, this is very helpful in disseminating disaster risk reduction measures. Disaster capacity building activities for youth are urgently needed so that the creation of a commitment and accuracy of activities and targets in order to realize youth readiness in facing disasters. Disasters can cause material damage and loss and even casualties which will ultimately disrupt the socioeconomic system of society.

\section{REVIEW OF LITERATURE}

\section{Regional Planning with Disaster Management}

According to Sumarsono (2010), "participatory planning is a method of development planning by involving community members who are positioned as the subject of development. According to the explanation of the Act. 25 of 2004 concerning the national development planning system: participatory planning is carried out by involving all parties with an interest in development. Their involvement is to get aspirations and create a sense of belonging". In Law no. 25 of 2004, also explains "community participation" is participation to accommodate their interests in the process of formulating development plans.

\section{The Concept of Effectiveness}

Soejono Soekanto (1986: 25) argues that effectiveness comes from the word effektivies which means the degree to which a group reaches its goals. H. Emerson in Handayaningrat (1994: 16) which states that effectiveness is a measurement in the sense of achieving predetermined goals. Sondang P. Siagian (2001: 24) argues that effectiveness is the use of a certain amount of resources, facilities and infrastructure that is consciously determined in advance to produce a number of goods for the services of the activities it carries out.

Duncan quoted in Richard M. Steers (1985: 53) states the measure of effectiveness, as follows:

a. Goal Achievement is the overall effort to achieve goals must be viewed as a process. Therefore, in order for the achievement of the final goal to be guaranteed, phasing is required, both in the sense of phasing in the achievement of its parts and phasing in the sense of periodization. Achievement of goals consists of several actors, namely: Time period and targets which are target congresses. 
b. Integration is a measurement of the level of an organization's ability to conduct socialization, consensus development and communication with various other organizations. Integration involves the socialization process.

c. Adaptation is an organization's ability to adapt to its environment. For this purpose, benchmarks are used for the procurement and labor filling process.

\section{The Role of Youth}

Meanwhile, according to Soekamto (2003: 243) role is a dynamic aspect of position (Status). When a person exercises his rights and obligations according to his position, he plays a role. Everyone has various roles that come from the patterns of social life. This also means that the role determines what it does for the community and what opportunities the community will give in carrying out a role. The role includes three things, namely:

1. Role includes norms related to one's position or place in society. The role in this sense is a series of rules that guide a person in community life.

2. The role is a concept of what can be done by individuals in society in organizations.

3. The role can also be said to be an important behavior for the social structure of society.

From the above explanation, it can be concluded that a role is an action / action of a person in a job / position, and if that person has exercised his rights and obligations in accordance with his job / position, it can be said that the person has carried out his role properly.

\section{Disaster}

Disaster is a series of events that threaten and disrupt people's lives and livelihoods caused by both natural and or non-natural factors as well as human factors resulting in human casualties, environmental damage, property losses, and psychological impacts (Law 24/2007). Eruptions usually occur on volcanoes which is a phenomenon of the release of magma from the bowels of the earth.

\section{Eruption Disaster Management}

Disaster volcano eruption management is divided into three parts, namely preparation before the eruption, during the eruption and after the eruption.

\section{Disaster Management}

Disaster management is a dynamic, continuous and integrated process to improve the quality of measures relating to disaster observation and analysis as well as prevention, mitigation, preparedness, early warning, emergency response, disaster rehabilitation and reconstruction (Law 24/2007). Disaster management activities are prevention, mitigation, preparedness, early warning, emergency response, emergency assistance, recovery, rehabilitation and reconstruction.

\section{RESEARCH METHODS}

This research uses qualitative methods in seeing phenomena related to policies and various kinds of problems. This study will use qualitative procedures in which the theory does not function as the concepts being tested, but rather as a means to sharpen data analysis (Muhadjir, 1989: 40). Locations in 3 villages located in Tiganderket Sub-District, Karo District North Sumatra Province are Perbaji Village, Suka Tendel Village, Mardinding Village. The methods of collecting data in this study are observation, interviews, and documentation. The informants were Sarjana Ginting as Village Disaster Management Authority-Secretary, Hasan Tarigan as the Perbaji Village Youth Figure, Jefri Singarimbun 
as Youth Figure in Mardinding Village, Agustinus Surbakti as Youth Figure in Tendel Village, and the three people of society around the research location that were impacted by Sinabung Volcano eruption. Supporting informants are youth groups who participate in the eruption of Sinabung Volcano Eruption.

Duncan stated that the effectiveness measure is the achievement of goals which is the overall effort to achieve goals must be viewed as a process, integration which is a process of socialization, and adaptation which is the ability of an organization to adapt to its environment. Youth play an active role as a moral force, social control, and agent of change in all aspects of national development in accordance with Law No.40 of 2009. Law No.24 of 2007 which states that there are several stages in disaster management, namely, the pre-disaster stage, the emergency response stage, and the post-disaster stage.

Data in this study were collected by interview, observation and document observation techniques. Data interpretation is an effort made by sorting and grouping data that has been collected from the field, either through observation, interviews and document studies. Data interpretation consists of several stages, namely: classification and categorization of data, data reduction, description and conclusion drawing. The technique of drawing conclusions will be done in a deductive way without making generalizations.

\section{RESULT AND DISCUSSION}

In an effort to achieve goals in 3 (three) phases of disaster management in three villages affected by the eruption of Sinabung Mountain in Tiganderket Sub-district in accordance with the results of interviews and field observations conducted only one phase in accordance with the objectives of disaster management namely the phase when a disaster occurs, village youth tend to do disaster management activities when a disaster is happening.

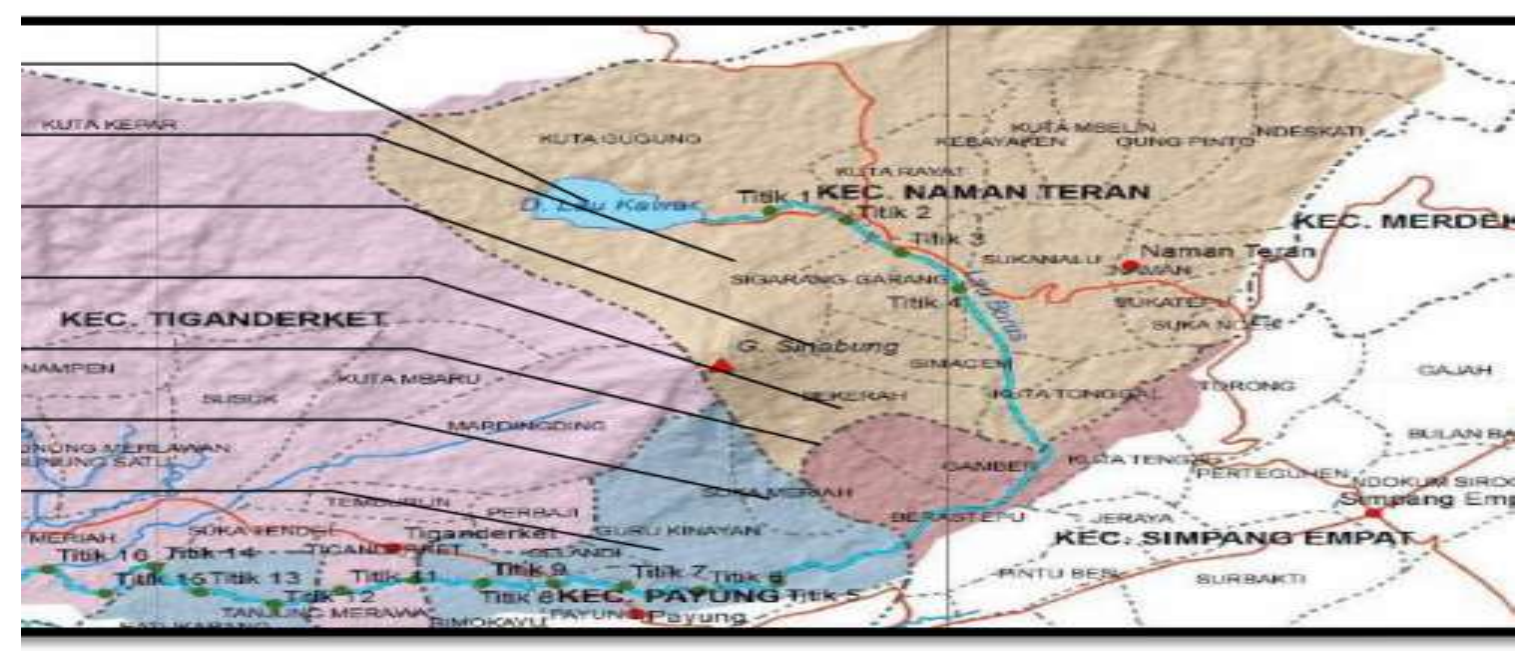

Figure 1. The map of Tiganderket Prone-Locations Get Disaster

\section{The effectiveness of the role of youth in handling the Mount Sinabung eruption disaster in Tiganderket District, Karo Regency}

\section{Achievement of objectives}

In an effort to achieve the goals in 3 (three) phases of disaster management in three villages affected by the eruption of Mount Sinabung in Tiganderket District, according to the results of interviews and field observations carried out only one phase is in accordance 
with the objectives of disaster management, namely the phase when a disaster occurs, village youth tend to do disaster management activities when a disaster is happening.

\section{Integration}

Integration is a measurement of the level of an organization's ability to conduct socialization, consensus development and communication with various other organizations. Integration involves the socialization process. In 3 (three) phases of disaster management, namely pre-disaster, when the disaster occurs and after the disaster. The level of youth's ability to knowledge about disasters is very low, it can be seen from the results of interviews conducted with Karnila Br.Singarimbun, who is a resident of Mardinding Village, she said that:

"Village youths have never received specific disaster management training so that their knowledge to carry out disaster management processes is minimal”.

Mr. Sarjana Ginting as Secretary of Karo district BPBD also said:

"Karo District BPBD does not have a special program to increase youth knowledge on disaster management, only in the near future we will have a disaster resilient village program that will be facilitated by disaster resilient village facilitators".

Table 1: The effectiveness of the role of youth in handling the eruption of Mount Sinabung, Tiganderket District, Karo Regency, North Sumatra.

\begin{tabular}{|c|c|c|c|c|c|c|c|c|c|c|}
\hline \multirow[t]{3}{*}{ No. } & \multirow[t]{3}{*}{ Village } & \multicolumn{9}{|c|}{ Effectiveness Indicator } \\
\hline & & \multicolumn{3}{|c|}{ Achievement } & \multicolumn{3}{|c|}{ Integration } & \multicolumn{3}{|c|}{ Adaptation } \\
\hline & & Less & Middle & High & Less & Middle & High & Less & Middle & High \\
\hline 1. & Perbaji & $\checkmark$ & & & $\checkmark$ & & & $\sqrt{ }$ & & \\
\hline 2. & Mardinding & $\checkmark$ & & & $\checkmark$ & & & $\checkmark$ & & \\
\hline 3 & Suka Tendel & $\checkmark$ & & & $\checkmark$ & & & $\checkmark$ & & \\
\hline \multicolumn{2}{|c|}{ Total } & 3 & $\mathbf{0}$ & $\mathbf{0}$ & 3 & $\mathbf{0}$ & $\mathbf{0}$ & 3 & $\mathbf{0}$ & $\mathbf{0}$ \\
\hline
\end{tabular}

Tabel 2. The Role of Youth in Disaster Management

\begin{tabular}{|c|c|c|}
\hline Phases & $\begin{array}{l}\text { The Role of Youth in } \\
\text { Disaster Management }\end{array}$ & Actions \\
\hline Pre-Disaster & $\begin{array}{l}\text { - Prevention } \\
\text { - Mitigation } \\
\text { - Preparedness }\end{array}$ & $\begin{array}{l}\text { - Not yet } \\
\text { - Not yet } \\
\text { - Not yet }\end{array}$ \\
\hline During- & - Early Wraning & - yet \\
\hline Disaster & $\begin{array}{l}\text { - Emergency Response } \\
\text { - Emergency Assistance }\end{array}$ & $\begin{array}{l}\text { - yet } \\
\text { - yet }\end{array}$ \\
\hline Post-Disaster & $\begin{array}{l}\text { - Rehabilitation } \\
\text { - Reconstruction }\end{array}$ & $\begin{array}{l}\text { - Not yet } \\
\text { - Not yet }\end{array}$ \\
\hline
\end{tabular}

As the above tables describe that three phases of disaster management are pre-disaster, when a disaster occurs and after a disaster. The level of ability of youth in disaster knowledge is very low. The lack of youth in Perbaji, Mardinding and Suka Tendel villages is one of the obstacles in youth involvement in disaster management efforts. Each village only has under \pm 30 young people living in the village who are also participating in making a living outside the village. In the process of adjustment when a disaster occurs, young 
people are certainly involved in only one phase, namely when a disaster occurs but the lacks a role to be involved in pre-disaster and post-disaster events.

\section{CONCLUSION}

1. Effectiveness of the role of youth in the eruption of Sinabung Mountain eruption.

a. Achievement of objectives

In an effort to achieve the goal of disaster management, of course there are three phases that will be carried out namely the pre-disaster phase, during the disaster and after the disaster. In the research process carried out by village youth only has a role in the event of a disaster. So that the achievement of disaster management goals is very low because there are two phases that are very minimal.

b. Integration

In disaster management efforts, there are three phases, namely pre-disaster, during disaster and post-disaster. In this phase the level of youth knowledge is very low regarding the efforts made in these phases so that integration in the eradication of Sinabung Mountain eruption can be seen through their low role in the phases of disaster management.

c. Adaptation

In disaster management efforts, there are three phases, namely pre-disaster, during disaster and post-disaster. In this phase the level of youth knowledge is very low because Karen youth cannot yet adapt to the current disaster environment.

2. This study analyzes three phases of disaster management that youth can play a role in:

a. Pre-disaster

The youths in Perbaji, Mardinding and Sukatendel Village lacked direct involvement in this phase, because Sinabung Mountain experienced a sudden eruption so there was no preparation and things done before the disaster occurred.

b. During a disaster

The village youth in Perbaji, Mardinding and Sukatendel Village had a very good role in this phase when the disaster occurred. They have an involvement in the disaster management process when the eruption of Sinabung Mountain is happening on their territory.

c. Post-Disaster

Village youth in Perbaji, Mardinding and Sukatendel Village did not have a role in the post-disaster phase because the village youth preferred to migrate and earn income outside the village or work individually to improve the family economy.

\section{REFERENCES}

Dunn, William N. (2000). Pengantar Analisis Kebijakan Publik. Gajah Mada University Press, Yogyakarta.

Efendi, Ferry. (2009). Keperawatan kesehatan komunitas: Teori dan Praktik dalam Keperawatan. Jakarta: Salemba Medika.

Handayaningrat, Soewarno. (1985). Sistem Birokrasi Pemerintah. CV: Mas Agung, Jakarta Heka, Hertanto. (2009). Manajemen Bencana Berbasis Masyarakat. Jakarta: Media Indonesia. 
Krech, D., Cruthfied, R. \&amp; Ballachey, E.(1962). Individual and Society. McGraw Hill. Kogakusha.

Kurniawan, Agung. (2005). Transformasi Pelayanan Publik, Pembaruan. Yogyakarta.

Mahmudi.(2005). Manajemen Kinerja Sektor Publik. Penerbit Buku UPP AMP YKPN. Yogyakarta.

Moekijat. (1980). Kamus Management. Penerbit Alumni, Bandung.

Moenir, H. A. S. (1995). Manajemen Pelayanan Umum di Indonesia. PT Bumi Aksara, Jakarta.

Moeleong, Lexi J. (2006). Metode Penelitian Kualitatif. Bandung: PT. Ramaja Rosdakarya.

Nawawi, Hadari. (1992). Manajemen Sumber Daya Manusia. Yogyakarta: Gajah Mada University Press.

Paripurno, Teguh. (2010). Manajemen Bencana Seputar Bencana di Indonesia. Jakarta: Media Indonesia

Rianto, Adi. (2004). Metode Penelitian Sosial dan Hukum. Jakarta: Granit.

Sedarmayanti. (2004). Good Governance (Kepemerintahan yang baik) Bagian Kedua: Membangun Sistem Manajemen Kinerja Guna Meningkatkan Produktifitas Menuju Good Governance (Kepemimpinan yang baik). Bandung: Mandar Manju.

Singarimbun, Masri, dan Sofyan Efendi. (2008). Metode Penelitian Survay. Jakarta: LP3ES.

Singarimbun, Masri. (1989). Metode penelitian Survey. Jakarta: PT. Pustaka LP3ES.

Soekanto, Soejono. (2003). Sosiologi suatu Pengantar. Jakarta: Raja Grafindo Persada.

Sugiyono. (2009). Metode Penelitian Pendidikan. Bandung: IKAPI.

Sutopo, Oki Rahadianto. (2017). Menjembatani Perspektif Budaya dan Perspektif Transisi dalam Kajian Kepemudaan. Published by LabSosio. Sociology study center FISIPUI. Accepted on July 2017 ; allowed: on August 2017. Accessed at $18^{\text {th }}$ November 2019, 00.45WIB.

Steers, Richard M. (1985). Efektivitas Organisasi. Erlangga, Jakarta.

Sources of law:

Minister of Home Affairs Regulation No. 46/2008 concerning establishment of BPBD.

Head of National Disaster Management Agency Regulation No. 3 of 2008 concerning Guidelines for the Establishment of a Regional Disaster Management Agency.

Law Number 24 of 2007 concerning Disaster Management.

Law Number 40 of 2009 concerning Youth Roles, Responsibilities, and Rights.

\section{Source of Internet:}

National Disaster Management Authority. Accessed from: http://www.bnpb.go.id/pengetahuan-bencana/definisi-dan-jenis-bencana. on November $19^{\text {th }}, 2018$.

Bramantyo Djohanputro. 2013. Manajemen Bencana (Disaster Management). Accessed from: $\quad$ https://manajemenppm.wordpress.com/2013/05/21/manajemen-bencanadisastermanagement/. on November $19^{\text {th }}, 2018$.

Gugyconcept. (2011). Penanggulangan Bencana Akibat Letusan Gunung. Accessed from: http://gugyconcept.blogspot.co.id/2011/06/penanggulangan-bencana-akibatletusan.html on November $28^{\text {th }}, 2018$.

Koko Wijayanto. (2012). Recognize: Pencegahan dan Manajemen Bencana. Accessed from: http://social-studies17.blogspot.com/2012/11/recognize-pencegahan-bencanadan.html. on November $26^{\text {th }}, 2018$. 
KSR Pekalongan.(2009). Definisi Penanggulangan Bencana. Accessed from: http://ksrpekalongan.blogspot.co.id/2009/05/definisi-penanggulangan-bencana.htm.On November 2018.

Maysandi. (2012). Manajemen Bencana, Manajemen Bencana Berbasis Masyarakat Dan Desertifikasi. http://maysandi.blogspot.co.id/2012/04/manajemenbencanamanajemen-bencana.html. on November $28^{\text {th }}, 2018$.

Moh Nurrofiq. (2017). Pengertian Erupsi dan Tanda-tanda Terjadinya Erupsi. Accessed from: $\quad$ http://www.diwarta.com/2012/03/21/pengertian-erupsi-dan-tanda-tandaterjadinya-erupsi.html. on November, $21^{\text {st }} 2018$.

Pemerintah Kabupaten Lamongan. Accessed from: http://lamongankab.go.id/instansi/bpbd/2014/02/21/pengertian-erupsi/. on November $28^{\text {th }}, 2018$.

Penataan Ruang. 2013. Undang-undang No. 24 Tahun 2007 tentang Penanggulangan Bencana. Accessed from: http://www.slideshare.net/perencanakota/undangundang-no24-tahun-2007-tentang-penanggulangan-bencana.on November 19 ${ }^{\text {th }}, 2018$. 